\title{
Transitional Cell to Tumor Cell Ratio Measurement
}

National Cancer Institute

\section{Source}

National Cancer Institute. Transitional Cell to Tumor Cell Ratio Measurement. NCI

Thesaurus. Code C154800.

The determination of the ratio of transitional cells compared to tumor cells present in a sample. The measurement may be expressed as a ratio or percentage. 